\title{
Cytogenotoxic effects of cypermethrin on root growth: Allium sativum as a model system
}

\author{
Temitope Olabisi Onuminya ${ }^{*}$, Tochukwu Emmanuel Eze \\ Department of Botany University of Lagos, Akoka, Lagos, Nigeria \\ Received 7th June 2019 / Accepted 28th August 2019
}

\begin{abstract}
Cypermethrin is a pyrethroid pesticide used on agricultural farms in Nigeria to control pests of fruits and vegetables but this is highly toxic to aquatic organisms. To determine toxicity of chemicals, Allium cepa is commonly used as an established bioassay however the bulb is used whole. Allium sativum in contrast is able to be split into cloves of smaller units hence this research aims to validate the potential of Allium sativum as a model plant for genotoxicity assessment. In this study, root growth inhibition test and chromosome aberration assay were used and the effective concentration $\left(\mathrm{EC}_{50}\right)$ of cypermethrin was determined from the root growth curve. Furthermore, the mitotic activities of the root meristem were assessed using light microscopy. Treatment of root meristem of $A$. sativum with various concentrations of cypermethrin $(0.25,0.50,0.75$ and $1.0 \mathrm{mg} / \mathrm{ml})$ revealed a reduction in the root length and $\mathrm{EC}_{50}$ of 0.44 $\mathrm{mg} / \mathrm{ml}$. Also morphological changes such root wilting, dark spots, tenderness of the clove bases and discoloration of the roots were observed. Cytological studies showed a reduction in mitotic index with increasing cypermethrin concentration. Chromosomal aberrations ranging from abnormal metaphases: cmetaphases, disturbed spindles and vagrant metaphases; to abnormal anaphases: laggard chromosomes, chromosome breaks and multipolarities were also recorded. These aberrations reduced with increased concentration of the pesticide leading to the production of lesser number of dividing cells. These show that cypermethrin is genotoxic to the root meristem and $A$. sativum is a suitable model plant for detecting pyrethroid genotoxicity in plant.
\end{abstract}

Keywords: Allium sativum, cytotoxicity, $\mathrm{EC}_{50}$, pesticides, pollution monitoring

\section{INTRODUCTION}

Pesticides have immensely contributed to the control of pests on farmlands, thereby increasing crop yields. However, they could also be detrimental to human health and ecosystem being one of the most important risks faced by farmers in the developing countries (Coronado et al., 2004).

Cypermethrin is a synthetic, pyrethroid insecticide that has high insecticidal property. It is commonly used in Nigerian farms to control many pests of fruits and vegetables. It is a fastacting neurotoxic and non-volatile chemical that is easily degraded in soil and plants. The use of cypermethrin has increased several-fold in recent years due to their low mammalian toxicity and limited persistence in soil as compared to organochlorine insecticides (Saxena et al., 2005). However, these compounds are highly toxic to

\footnotetext{
*Author for correspondence: Temitope Olabisi Onuminya, Department of Botany University of Lagos, Akoka, Lagos, Nigeria. Email tadeyemi@unilag.edu.ng
} 
fish (Ullah et al., 2018) and other lower aquatic organisms (Dalhoff, 2018) and their widespread use have led to toxic effects in plants, animals and humans (Datta et al., 2003; Biondi et al., 2015; Renu et al., 2017; Yao et al., 2019). The variation in toxicity among organisms may largely be due to differences in their stereo-chemical structures.

The root tips of many plants have long been used as an indicator for chromosome aberration and bioassay studies owing to the fact that plant chromosomes when treated with mutagens produce responses similar to mammals and other eukaryotes hence a number of plant bioassays have been developed to detect environmental mutagens (Grant, 1994). In vivo cytotoxicity tests, using plant such as Allium cepa, have been found to be as effective as in vitro animal testing (Teixeira et al., 2003; Ribeiro et al., 2016), providing valuable information for human health (Ullah et al., 2018). El-Shahaby et al. (2003) stressed the importance of using the Allium cepa test for detecting genotoxicity and evaluating environmental pollution. The plants possess some advantages over other organisms in certain circumstances; it has large chromosomes, low chromosome number and the root meristem contains a high proportion of cells in mitosis (Leme and Marin-Morales, 2009). However, the whole onion bulb has to be used for study of each mutagene hence the need to find an alternately effective plant for bioassay studies. Allium sativum, the common garlic, belongs to the family Alliaceae and genus Allium, it contains chromosomes of similar size and number as Allium cepa and it is also used as a sensitive test system for the evaluation of environmental pollutants and screening of chemicals with genotoxic effects, especially in plants (Saxena et al., 2009; Hemavathi et al., 2015). Unlike A. cepa, A. sativum has the ability to split into natural cloves, this makes it suitable for laboratory work as the clove roots can easily be subjected to singular treatments as against the whole bulb used in Allium cepa. This study therefore aims to validate the effectiveness of Allium sativum as a plant model for determining the genotoxic effects of pyrethroid pesticides on plants. It is hoped that this will prove an adequate replacement for Allium cepa in bioassay studies.

\section{MATERIALS AND METHOD}

\section{Test chemical}

A commercial formulation of cypermethrin (trade name: Cyperkill) with a composition of $1.0 \mathrm{mg} / \mathrm{ml}$ of the solution was purchased from the market for the experiment.

\section{Test organism}

Healthy and equal-sized Allium sativum bulbs were properly evaluated prior to purchase. The dry scales of the bulbs were removed and discoid stem of the bulbs were suspended in water for 4 days to ensure proper growth of the roots.

\section{Experimental design}

Completely randomized design was adopted for the study. The cypermethrin formulation was made into normal concentration of $0.25 \mathrm{mg} / \mathrm{ml}$, suitable for application in agricultural farms, 0.50 $\mathrm{mg} / \mathrm{ml}, 0.75 \mathrm{mg} / \mathrm{ml}$ and $1.0 \mathrm{mg} / \mathrm{ml}$ undiluted treatments ( $\mathrm{T}$ ) for the experiment with distilled water (C) as a negative control and five replications each for both the microscopic and macroscopic studies.

\section{Test procedures}

\section{Root inbibition test}

The macroscopic assessment involved placing the Allium sativum cloves in containers filled with the treatments at room temperature and this was observed daily for 3 days (Fig 1). Parameters such as root length, colour and number of roots were recorded.

\section{Chromosome aberration assay}

This was achieved following Saxena et al. (2009), Yekeen and Adeboye, (2013), and Renu et al. (2017). The Allium sativum seedlings were treated over $24 \mathrm{~h}$ for the microscopic studies. Microscopic analysis was carried out over a cell cycle $(24 \mathrm{~h})$ at $6 \mathrm{~h}$ interval. The root tips were harvested and fixed in acetic-ethanol (1:3) for $4 \mathrm{~h}$; they were hydrolyzed in $1 \mathrm{~N} \mathrm{HCl}$ for 6 mins at $60^{\circ} \mathrm{C}$ and then analyzed for mitotic irregularities. This was done at the $6^{\text {th }}, 12^{\text {th }}, 18^{\text {th }}$ and $24^{\text {th }}$ hour. The conventional Feulgen-squash method was used to prepare the slides of the root meristems. The slides were mounted on Olympus compound light microscope and observed under 
magnifications of $400 \mu \mathrm{m}$. Photomicrographs were taken and the mitotic index and chromosome aberrations in mitotic phases was determined. The mitotic index was obtained as follows:

$$
\begin{aligned}
\text { Mitotic index }(\mathrm{MI})= & \begin{array}{l}
\text { Number of cells in mitosis } \div \\
\text { Total number of cells }) \times 100
\end{array}
\end{aligned}
$$

\section{Statistical analysis}

The means root lengths and standard errors for different concentrations were calculated. The data obtained for each treated group and control were statistically evaluated by Analysis of Variance and Fisher's Least Significant Difference (FLSD) test at $5 \%$ significant level. The mitotic indices were also analyzed using ANOVA and FLSD. Also the half maximal effective concentration $\left(\mathrm{EC}_{50}\right)$ was determined.

\section{RESULTS}

\section{Root inhibition test}

Treatment of root meristem of $A$. sativum with various concentrations of cypermethrin revealed a reduction in the root length compare to the control. This suppression of root growth varies with the cypermethrin concentration and was followed by different morphological changes ranging from dark spots (after $24 \mathrm{~h}$ ) to tenderness of the clove bases and discoloration of the roots (after $48 \mathrm{~h}$ ) (Figure 1). The roots in $0.50 \mathrm{mg} / \mathrm{ml}$ solution were slightly discolored after $72 \mathrm{~h}$ exposure with no signs of wilt or decay while the roots in the $0.25 \mathrm{mg} / \mathrm{ml}$ solution remained unchanged. Differences in mean root lengths were significant $(\mathrm{p} \leq 0.05)$ between different concentrations as well as with control (Table 1). The mean root length (percent control) was plotted against the pesticide concentration (Figure 2). The $\mathrm{EC}_{50}$ of the pesticide was evaluated from the graph to be at $44 \%$ of the concentration.

\section{Chromosome aberration assay}

Treatments of the Allium sativum root meristem with the different concentrations of cypermethrin produced results with lower mitotic index compared to the control (Table 2). Mitotic activities were significantly lower $(\mathrm{p} \leq 0.05)$ in the treatments when compared to the control; this was dose dependent and decreased as the concentration of cypermethrin increased. Dividing cells were higher in the control than the treatments and the number of dividing cells decreased as the concentration of cypermethrin increased. Cypermethrin concentration of 0.25 $\mathrm{mg} / \mathrm{ml}$ with treatment duration of $6 \mathrm{~h}$ produced the lowest mitotic inhibition and highest number of dividing cells while complete mitotic inhibition was recorded for roots exposed to $1.00 \mathrm{mg} / \mathrm{ml}$ regardless of the exposure duration. Mitotic index of cells exposed to the cypermethrin for $6 \mathrm{~h}$ reduced significantly with increasing concentration of the chemical. The means were separated using the Least Significant Difference $\left(\mathrm{LSD}_{0.05}\right)$ and these showed significant differences between treatments as well as with control (Table 2).

Table 1. Root length of A. sativum treated with cypermethrin (Mean \pm S.E.)

\begin{tabular}{ccccc}
\hline $\begin{array}{c}\text { Concentration } \\
(\mathbf{m g} / \mathbf{m l})\end{array}$ & Before exposure & After exposure & $\begin{array}{c}\text { Increase in root } \\
\text { length }\end{array}$ & $\begin{array}{c}\text { Root length (\% } \\
\text { control) }\end{array}$ \\
\hline Control & $3.24 \pm 0.20^{\mathrm{a}}$ & $4.66 \pm 0.24^{\mathrm{d}}$ & $1.44 \pm 0.04$ & 100 \\
0.25 & $2.80 \pm 0.14^{\mathrm{a}}$ & $3.68 \pm 0.15^{\mathrm{c}}$ & $0.88 \pm 0.01$ & 51.1 \\
0.50 & $3.04 \pm 0.27^{\mathrm{a}}$ & $3.54 \pm 0.16^{\mathrm{bc}}$ & $0.50 \pm 0.11$ & 24.7 \\
0.75 & $2.98 \pm 0.37^{\mathrm{a}}$ & $3.16 \pm 0.12^{\mathrm{b}}$ & $0.18 \pm 0.25$ & 12.5 \\
1.00 & $2.76 \pm 0.22^{\mathrm{a}}$ & $2.76 \pm 0.09^{\mathrm{a}}$ & 0 & 0 \\
\hline
\end{tabular}

NB: Treatment means with same superscripts are not significantly different at $5 \%$. 

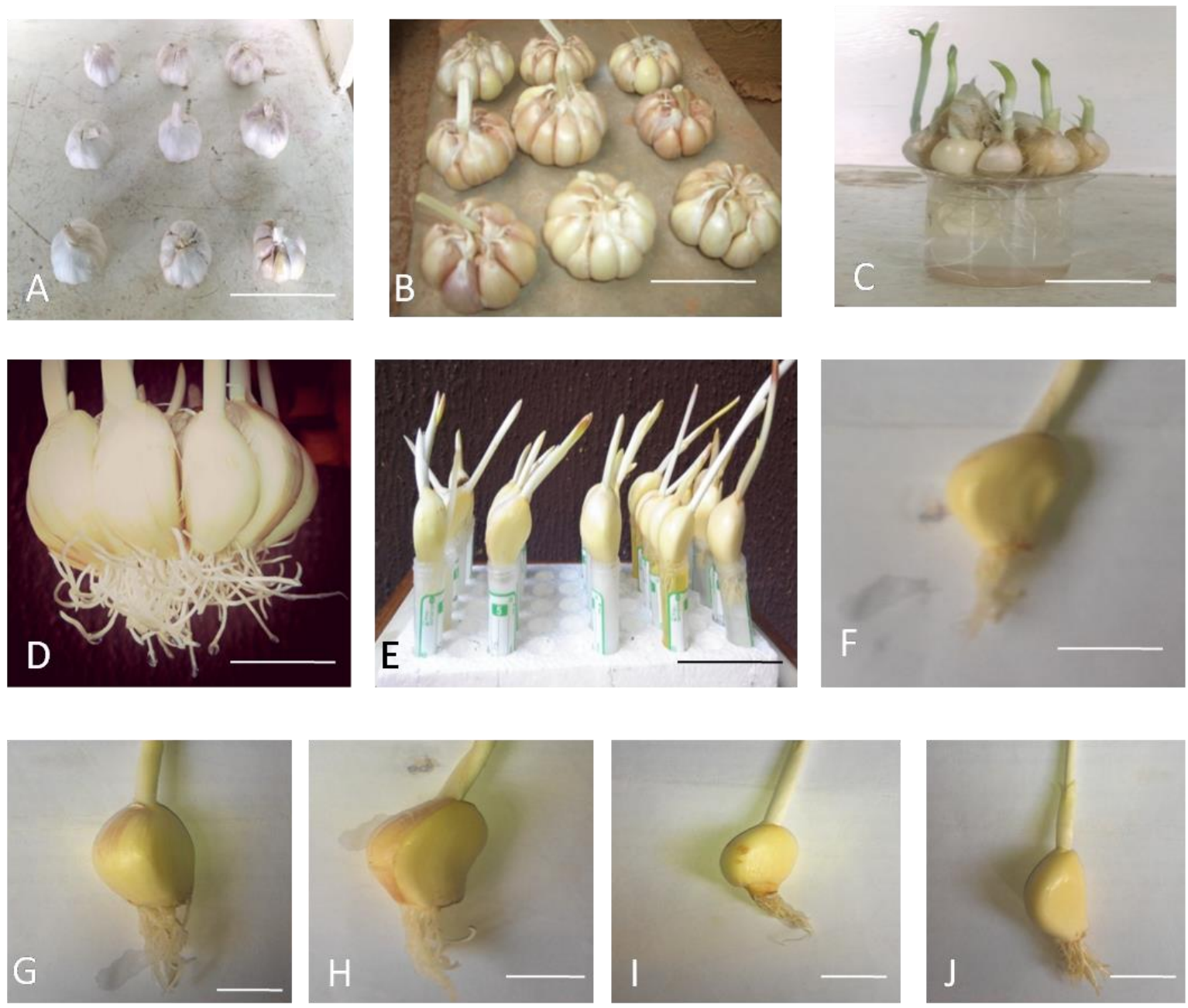

Figure 1. A. sativum bulbs selected for the experiment (A) with their dry scales intact; (B) with their scales removed; (C) Suspension in water for root growth initiation; (D) after root formation, and before treatment; $(\mathrm{E})$ in the treatment containers $(\mathrm{F}, \mathrm{G}, \mathrm{H})$ softened roots after exposure to $\mathrm{T}_{1}, \mathrm{~T}_{2}$ and $\mathrm{T}_{3}$ respectively; (I) dried roots after exposure to T4; (J) control. Magnification - x1.

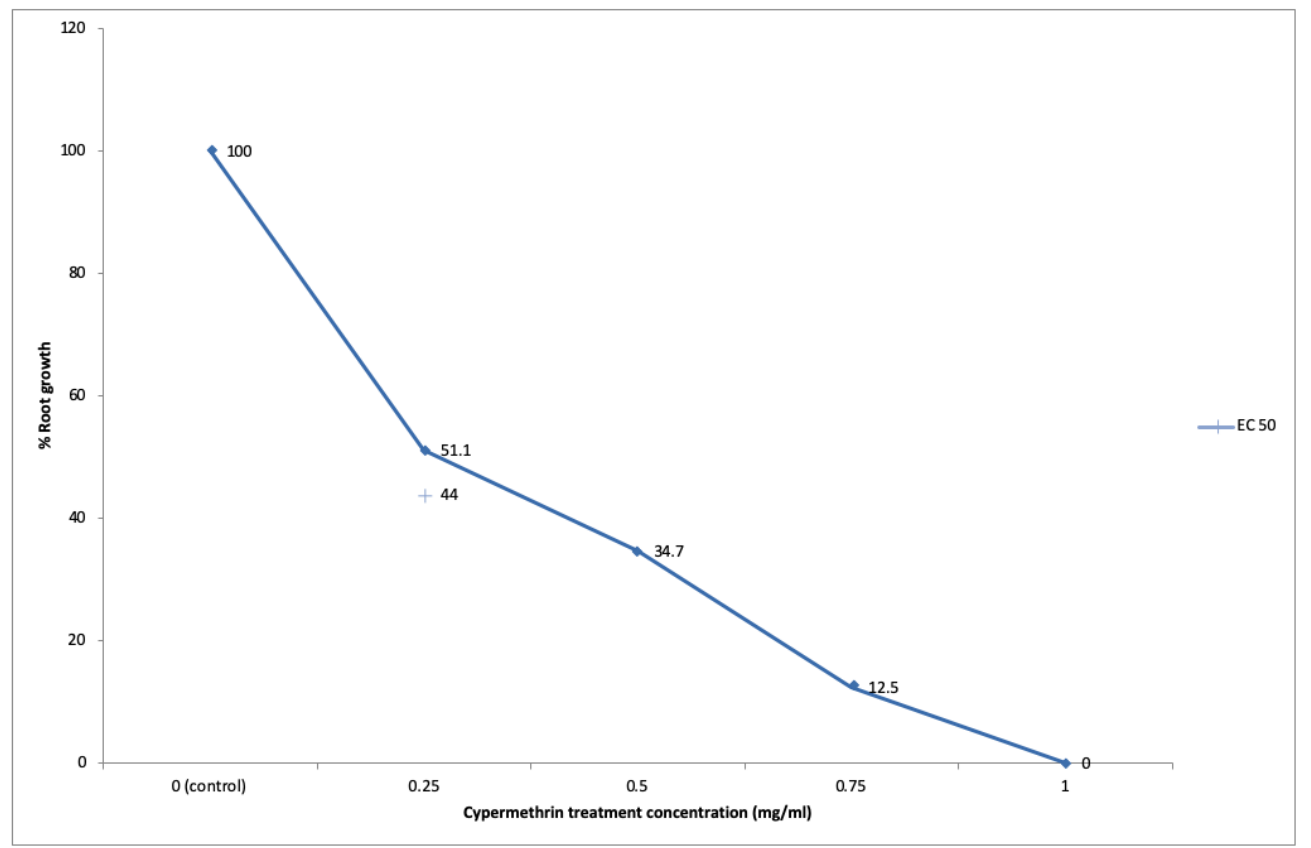

Figure 2. Effective Concentration $\left(\mathrm{EC}_{50}\right)$ of cypermethrin on root meristem of $A$. sativum. 
Table 2. Mean number of dividing cells and mitotic index of Allium sativum root tip treated with cypermethrin.

\begin{tabular}{cccc}
\hline Treatment $(\mathbf{m g} / \mathbf{m l})$ & Duration $\mathbf{( h )}$ & $\begin{array}{c}\text { Number of dividing } \\
\text { cells }\end{array}$ & $\begin{array}{c}\text { Mitotic index (Mean } \mathbf{~} \\
\text { S.E.) }\end{array}$ \\
\hline Control & & 106 & $31.86 \pm 1.02^{\mathrm{d}}$ \\
\hline $\mathrm{T}_{1(0.25)}$ & 6 & 86 & $28.66 \pm 0.77 \mathrm{c}$ \\
$\mathrm{T}_{2(0.50)}$ & 6 & 60 & $20.06 \pm 0.84^{\mathrm{b}}$ \\
$\mathrm{T}_{3(0.7)}$ & 6 & 39 & $13.12 \pm 0.56^{\mathrm{a}}$ \\
$\mathrm{T}_{4(1.00)}$ & 6 & 0 & 0 \\
\hline $\mathrm{T}_{1(0.25)}$ & 12 & 81 & $26.88 \pm 0.38^{\mathrm{c}}$ \\
$\mathrm{T}_{2(0.50)}$ & 12 & 55 & $18.34 \pm 0.92^{\mathrm{b}}$ \\
$\mathrm{T}_{3(0.75)}$ & 12 & 32 & $10.66 \pm 0.72^{\mathrm{a}}$ \\
$\mathrm{T}_{4(1.00)}$ & 12 & 0 & 0 \\
\hline $\mathrm{T}_{1(0.25)}$ & 18 & 76 & $25.26 \pm 0.80^{\mathrm{c}}$ \\
$\mathrm{T}_{2(0.50)}$ & 18 & 50 & $16.60 \pm 0.93^{\mathrm{b}}$ \\
$\mathrm{T}_{3(0.75)}$ & 18 & 32 & $7.54 \pm 0.76^{\mathrm{a}}$ \\
$\mathrm{T}_{4(1.00)}$ & 0 & 0 \\
\hline $\mathrm{T}_{1(0.25)}$ & 18 & 70 & $23.26 \pm 1.39 \mathrm{c}$ \\
$\mathrm{T}_{2(0.50)}$ & 24 & 43 & $14.48 \pm 1.07 \mathrm{~b}$ \\
$\mathrm{~T}_{3(0.75)}$ & 24 & 11 & $3.68 \pm 0.37^{\mathrm{a}}$ \\
$\mathrm{T}_{4(1.00)}$ & 24 & 0 & 0 \\
\hline
\end{tabular}

Mitotic index was scored in a total of 300 cells.

NB: Treatment means with same superscripts are not significantly different at 5\%.

Table 3. Number of chromosomal aberrations observed in $A$. sativum roots treated with cypermethrin.

\begin{tabular}{cccccccc}
\hline Treatments & $\begin{array}{c}\text { Duration } \\
\text { (h) }\end{array}$ & MA & CB & LC & DS/c-M & Vm & Cbr \\
\hline T1 & 6 & 0 & 0 & 0 & 0 & 1 & 0 \\
T1 & 12 & 0 & 0 & 0 & 2 & 4 & 0 \\
T1 & 18 & 0 & 0 & 1 & 2 & 3 & 0 \\
T1 & 24 & 1 & 0 & 0 & 1 & 5 & 0 \\
\hline T2 & 6 & 1 & 2 & 1 & 3 & 4 & 0 \\
T2 & 12 & 1 & 4 & 2 & 2 & 5 & 0 \\
T2 & 18 & 2 & 3 & 5 & 3 & 10 & 1 \\
T2 & 24 & 0 & 1 & 2 & 1 & 5 & 2 \\
\hline T3 & 6 & 2 & 3 & 1 & 1 & 7 & 2 \\
T3 & 12 & 2 & 2 & 1 & 0 & 6 & 1 \\
T3 & 18 & 1 & 2 & 0 & 0 & 3 & 2 \\
T3 & 24 & 1 & 1 & 2 & 0 & 1 & 1 \\
T4 & 6 & 0 & 0 & 0 & 0 & 0 & 0 \\
T4 & 12 & 0 & 0 & 0 & 0 & 0 & 0 \\
T4 & 18 & 0 & 0 & 0 & 0 & 0 & 0 \\
T4 & 24 & 0 & 0 & 0 & 0 & 0 & 0 \\
\hline
\end{tabular}

MA=Multipolar Anaphase; CB=Chromosome bridge; LC=Laggard Chromosome; DS/c-M=Disturbed Spindle c-Metaphase; VM=Vagrant Metaphase; CBr Chromosome breaks.

The chromosomes were observed at prophase, metaphase, anaphase and telophase stages (Figure 3). Different kinds of chromosomal aberrations were found in the cells treated with cypermethrin however, the number of aberrations did not increase with increasing cypermethrin concentration (Table 3). The most frequent aberrations observed were related to the metaphase and anaphase stages. These were vagrant metaphases, chromosome breaks, disturbed spindles and c-metaphases; chromosome laggards, vagrant quadruple anaphases, tripolar anaphases and chromosome bridges (Figure 4).

There was significant difference only in telophase index after $6 \mathrm{~h}$, only prophase index after $12 \mathrm{~h}$ but no significant difference in prophase, metaphase, anaphase and telophase indices after 18 and $24 \mathrm{~h}$ of treatment period (Table 4). 

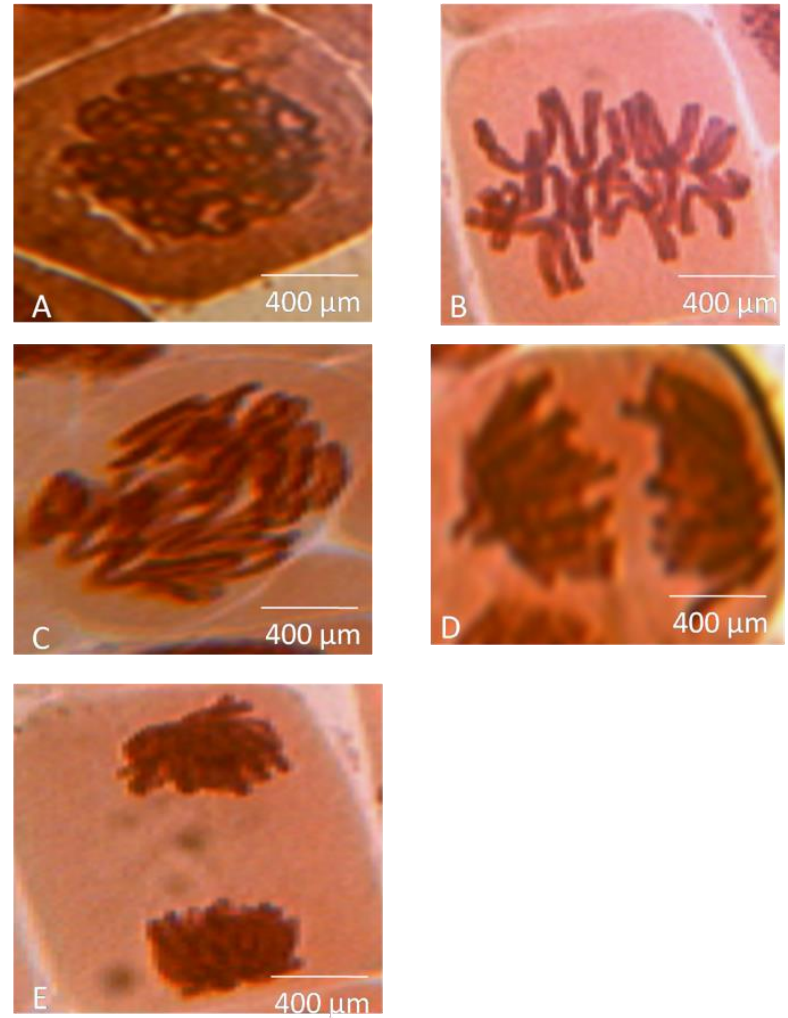

Figure 3. Normal mitotic stages observed in $A$. sativum treated with cypermethrin. (A) Normal prophase; (B) Normal metaphase with the chromosomes aligned at the plate; (C) Normal early anaphase - chromosomes are migrating towards the poles; (D) Normal late anaphase chromosomes have reached the poles; (E) Normal telophase.
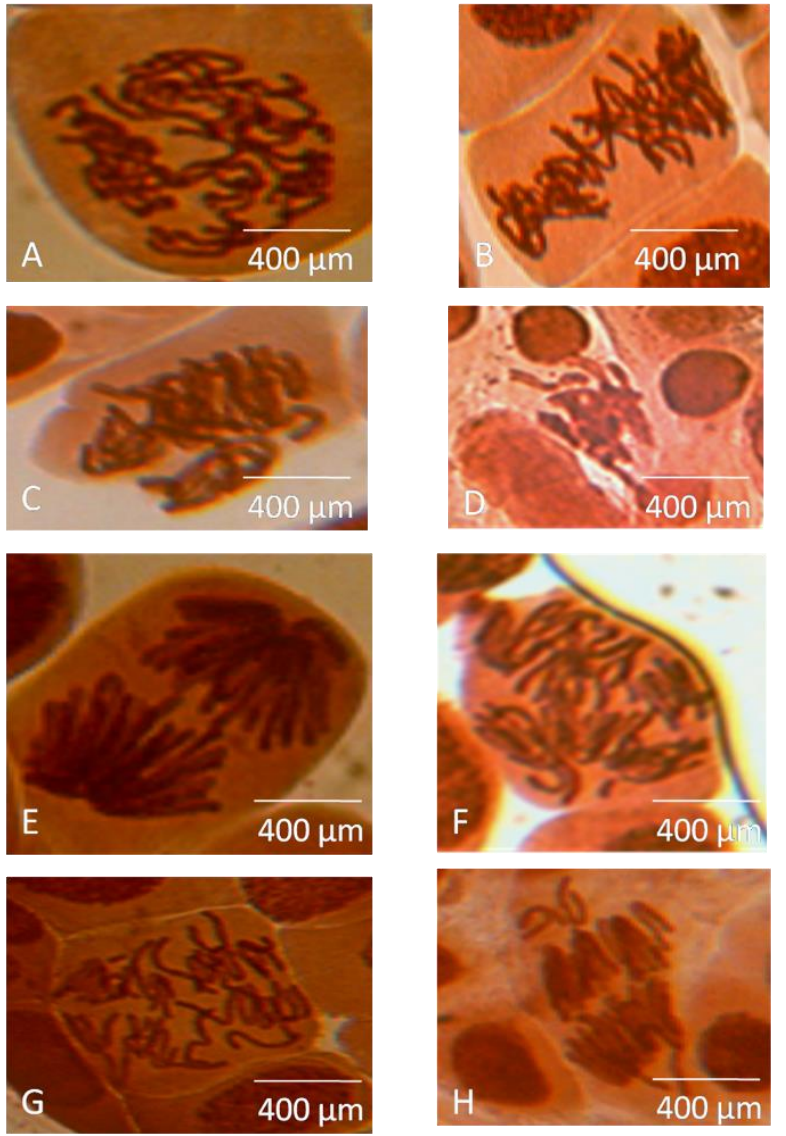

Figure 4. Aberrant mitotic stages observed in $A$. sativum treated with cypermethrin. A-D: Abnormal metaphase with; (A) c-metaphase: unorganized chromosomes, (B) disturbed spindle, (C) vagrant chromosomes, (D) chromosome break. E-H: Abnormal anaphase with: (E) chromosome bridge, (F) multipolar anaphase with vagrant chromosome, $(\mathrm{G})$ multipolar anaphase quadruple anaphase, $(\mathrm{H})$ laggard chromosome

Table 4. Phase index of $A$. sativum root treated with cypermethrin.

\begin{tabular}{cccccc}
\hline Duration (h) & Treatment & Prophase & Metaphase & Anaphase & Telophase \\
\hline 6 & Control & $27.66 \pm 1.62^{\mathrm{a}}$ & $24.56 \pm 1.66^{\mathrm{a}}$ & $22.06 \pm 3.84^{\mathrm{a}}$ & $25.76 \pm 3.23^{\mathrm{b}}$ \\
6 & T1 & $29.32 \pm 2.19^{\mathrm{a}}$ & $31.50 \pm 2.03^{\mathrm{a}}$ & $27.98 \pm 1.4^{\mathrm{a}}$ & $11.20 \pm 2.22^{\mathrm{a}}$ \\
6 & T2 & $30.22 \pm 3.28^{\mathrm{a}}$ & $28.56 \pm 2.17^{\mathrm{a}}$ & $22.38 \pm 1.75^{\mathrm{a}}$ & $18.76 \pm 3.84^{\mathrm{ab}}$ \\
6 & T3 & $26.60 \pm 2.21^{\mathrm{a}}$ & $25.96 \pm 1.08^{\mathrm{a}}$ & $21.30 \pm 1.33^{\mathrm{a}}$ & $24.92 \pm 4.03^{\mathrm{b}}$ \\
\hline 12 & Control & $0.18 \pm 2.46^{\mathrm{b}}$ & $27.44 \pm 2.00^{\mathrm{a}}$ & $20.62 \pm 1.96^{\mathrm{a}}$ & $21.72 \pm 1.70^{\mathrm{a}}$ \\
12 & T1 & $23.06 \pm 1.49^{\mathrm{a}}$ & $24.64 \pm 3.49^{\mathrm{a}}$ & $26.10 \pm 2.5^{\mathrm{a}}$ & $26.30 \pm 3.19^{\mathrm{a}}$ \\
12 & T2 & $30.74 \pm 2.35^{\mathrm{b}}$ & $26.10 \pm 2.99^{\mathrm{a}}$ & $20.58 \pm 2.38^{\mathrm{a}}$ & $25.32 \pm 4.97^{\mathrm{a}}$ \\
12 & T3 & $22.44 \pm 2.55^{\mathrm{a}}$ & $26.82 \pm 2.51^{\mathrm{a}}$ & $22.28 \pm 3.16^{\mathrm{a}}$ & $28.38 \pm 4.69^{\mathrm{a}}$ \\
\hline 18 & Control & $27.30 \pm 3.29^{\mathrm{a}}$ & $30.48 \pm 1.86^{\mathrm{a}}$ & $22.44 \pm 2.46^{\mathrm{a}}$ & $19.54 \pm 1.76^{\mathrm{a}}$ \\
18 & T1 & $28.22 \pm 1.87^{\mathrm{a}}$ & $28.30 \pm 3.14^{\mathrm{a}}$ & $23.50 \pm 2.25^{\mathrm{a}}$ & $19.84 \pm 3.46^{\mathrm{a}}$ \\
18 & T2 & $32.88 \pm 4.65^{\mathrm{a}}$ & $26.90 \pm 3.18^{\mathrm{a}}$ & $23.86 \pm 3.37^{\mathrm{a}}$ & $15.82 \pm 3.72^{\mathrm{a}}$ \\
18 & T3 & $21.66 \pm 3.25^{\mathrm{a}}$ & $23.66 \pm 2.62^{\mathrm{a}}$ & $29.04 \pm 4.84^{\mathrm{a}}$ & $25.42 \pm 5.64^{\mathrm{a}}$ \\
\hline 24 & Control & $29.92 \pm 2.71^{\mathrm{a}}$ & $25.16 \pm 1.36^{\mathrm{a}}$ & $23.44 \pm 3.10^{\mathrm{a}}$ & $21.42 \pm 2.68^{\mathrm{a}}$ \\
24 & T1 & $26.42 \pm 2.36^{\mathrm{a}}$ & $25.48 \pm 1.87^{\mathrm{a}}$ & $23.18 \pm 2.21^{\mathrm{a}}$ & $25.96 \pm 1.99^{\mathrm{a}}$ \\
24 & T2 & $26.88 \pm 2.78^{\mathrm{a}}$ & $26.44 \pm 3.91^{\mathrm{a}}$ & $21.32 \pm 2.77^{\mathrm{a}}$ & $25.96 \pm 3.92^{\mathrm{a}}$ \\
24 & T3 & $21.26 \pm 4.92^{\mathrm{a}}$ & $21.86 \pm 5.26^{\mathrm{a}}$ & $34.82 \pm 7.08^{\mathrm{a}}$ & $22.66 \pm 1.58^{\mathrm{a}}$ \\
\hline
\end{tabular}

NB: Treatment means with same superscripts are not significantly different at 5\%. 


\section{DISCUSSION}

Results from this study provide evidence that cypermethrin inhibited root growth and caused root wilt at higher concentrations. The inhibition of growth, according to Grover and Tejpar (1981), may be due to high rate of chemical oxygen demand which affected certain physiological processes leading to the disturbance in the balance between promoters and inhibitors of endogenous growth regulator. There was marked decrease in root length after treatment when compared to the control; this according to Odeigah et al; (1997) is an indication of cytotoxicity. The $\mathrm{EC}_{50}$ was achieved at 0.44 $\mathrm{mg} / \mathrm{ml}(44 \%)$. This $\mathrm{EC}_{50}$ value is greater than the $0.24 \mathrm{mg} / \mathrm{ml}$ reported by Saxena et al. (2005) and $0.28 \mathrm{mg} / \mathrm{ml}$ recorded by Yekeen et al. (2013) in their study of the effects of cypermethrin on $A$. cepa. This indicates that $A$. sativum is more sensitive than $A$. cepa to cypermethrin and corroborates the findings of Saxena et al. (2008).

The chromosome aberration assay revealed clear evidence of the genotoxic potential of cypermethrin. Aberrations of mitotic cycle, change of mitotic index and chromosomal abnormalities observed after exposure to toxic metals, metalloids or organic pollutants were attributed to the disorganization and depolymerization of microtubules, which underlie these processes in higher plant cells (Liu et al., 2009). The wide range of observed abnormalities is more evident in metaphase and anaphase. This suggests that even short term exposure to relatively small concentrations of cypermethrin can significantly ( $\mathrm{p} \leq 0.05)$ affect the mitotic index, chromosome structure and disturbs mitotic spindle formation. The chromosomal fragments according to Hemavathi et al. (2015) can be attributed either to chromosomal breakages in anaphase bridges and metaphase due to cohesive chromosomal translocations or multiple breakages of the chromosome due to loss of chromosome integrity. The chromosome bridges seen is an indication of clastogenic effect caused by chromosome breaks, vagrant chromosomes and c-metaphases show an increased risk for aneuploidy in the plant while sticky chromosomes is an indication of a highly toxic, irreversible effect which may lead to cell death (Ping et al., 2012).
Mitotic index of root tips treated with cypermethrin decreased significantly as the exposure duration increased. This shows that the inhibition of mitosis in Allium sativum roots by cypermethrin is dependent on the treatment time. However, reduction in mitotic index was greater across concentration than across exposure duration. The lowering of mitotic index in the treated root tips could be due to inhibition of DNA synthesis (Sudhakar et al., 2001), arrest of one or more mitotic phases (Kabarity et al., 1980) or blocking of G2 phase in the cell cycle (ElGhamery et al., 2000) preventing the cell from entering mitosis. The reduction in mitotic activity with increasing concentrations clearly demonstrated the ability of the pesticide to inhibit DNA synthesis.

The results obtained from the study indicate the genotoxicity of cypermethrin to $A$. sativum root meristem cells with even very minute concentration of the chemical showing significant toxicity to the cells. Also, chromosomal aberrations induced by cypermethrin are not dose-dependent as aberrations depend on the number of cells undergoing mitosis. Having obtained a cypermethrin concentration that produced result with lower cytotoxic effects than the concentration currently used on farms, it is therefore recommended that entomologists should test the efficacy of this concentration on pests. This concentration is below the $\mathrm{EC}_{50}$ value and may pose less threat to man, animals and plants.

In conclusion, this study has validated the utility of root cells of $A$. sativum for monitoring the genotoxic effects of cypermethrin and enabled the assessment of genetic endpoints such as mitotic index and chromosome aberration.

\section{REFERENCES}

Biondi, A., Zappalà, L., Desneux, N., Aparo, A., Siscaro, G., Rapisarda, C., Martin, T., \& Garzia G. T. 2015. Potential toxicity of $\alpha$-Cypermethrin-treated nets on Tuta absoluta (Lepidoptera: Gelechiidae). Journal of Economic Entomology 108(3): 1191-1197.

Coronado, G. D., Thompson, B., Strong, L., Griffith, W. C., \& Islas, I. 2004. Agricultural task and exposure to organophosphate pesticides among farm workers. Environmental Health Perspective 112:142-147.

Dalhoff, K. 2018. Aquatic toxicity of Cypermetbrin. Thesis PhD. Department of Plant and Environmental Sciences, Faculty 
of Science, University of Copenhagen. https://www.forskningsdatabasen.dk/en/catalog/243882 6678

Datta, M. \& Kaviraj, A. 2003. Acute toxicity of the synthetic pyrethroids deltamethrin to freshwater cat fish Clarias gariepinus. Bulletin of Environmental Contamination and Toxicology 70: 296-299.

El-Ghamery, A. A., El-Nahas A. I., \& Mansour M. M. 2000. The action of atrazine herbicide as an inhibitor of cell division on chromosomes and nucleic acids content in root meristems of Allium cepa and Vicia faba. Cytologia 65: 277287.

El-Shahaby, O. A., Abdel-Migid, H. M., Solmon, M. I., \& Mashahy, I. A. 2003. Chromosome aberration assay. Pakistan Journal of Biological Sciences 6(1): 23-28.

Grant, W. F. 1994. The present status of higher plant bioassays for the detection of environmental mutagens. Mutation Research 310: 175-185.

Grover, I. S. \& Tejpar, S. K. 1981. Antagonistic effect of gamma radiation on dormant seed Avena fatua. Radiation Botany 15: 435-450.

Hemavathi, K. L., Hemanth Kumar, N. K., \& Shobha, J. 2015. Genotoxic effect of distillery effluent on root tip cells of Allium sativum L. Journal of Applied Biology \& Biotechnology, 3(2): 038-041.

Kabarity, A. \& Mallalah, G. 1980. Mitodepressive effect of Khat extract in the meristematic region of Allium cepa root tips. Cytologia 45: 733-738.

Liu, D., Xue, P., Meng, Q., Zou, J., Gu, J., \& Jiang, W. 2009. Pb/Cu effects on the organization of microtubule cytoskeleton in interphase and mitotic cells of Allium sativum L. Plant Cell Reports 28: 695-702.

Odeigah, P. G. C, Makinwa, J., Lawal, B., \& Oyeniyi, R. 1997. Genotoxicity screening of leachates from solid industrial waste evaluated Allium test. American Theological Library Association (ATLA) 25: 311-321.

Ping, K. Y., Darah, I., Yusuf, U. K., Yeng, C., \& Sasidharan, S. 2012. Genotoxicity of Euphorbia birta: An Allium cepa Assay. Molecules 17: 7782-7791.

Renu, S., Srivastava, A. K. \& Gangwar, N. K. 2017. Cypermethrin and sodium fluoride induced haematological studies on male Wistar rats. Veterinary Practitioner 18(1): 59-62

Ribeiro, T. P., Sousa, T. R., Arruda, A. S., Peixoto, N., Gonçalves, P. J., \& Almeida, L. M. 2016. Evaluation of cytotoxicity and genotoxicity of Hancornia speciose latex in Allium cepa root model. Brazilian Journal of Biology, 76(1).

Saxena, P. N., Chauhan, L. K. S., \& Gupta, S. K. 2005. Cytogenetic effects of commercial formulation of cypermethrin in root meristem cells of Allium sativum: Spectroscopic basis of chromosome damage. Toxicology 216: 244-252.

Saxena, P. N., Murthy, R. C., \& Gupta, S.K. 2009. Evaluation of cytogenetic effects of deltamethrin in root meristem cells of Allium sativum and Allium cepa: A possible mechanism of chromosome damage. Toxicological and Environmental Chemistry 91(3): 577-594.

Teixeira, R. O., Comparoto, M. L., Mantovani, M. S., \& Vicentini, V. E. P. 2003. Assessment of two medicinal plants: Psidium guajava $L$. and Achulea millefolium $L$., in vitro and in vivo assays. Genetics and Molecular Biology 226: 551-555.

Ullah, S., Zuberi, A., Alagawany, M., Farag, M. R., Dadar, M., Karthik, K., Tiwari, R., Dhama, K., \& Iqbal, H. M. N. 2018. Cypermethrin induced toxicities in fish and adverse health outcomes: Its prevention and control measure adaptation. Journal of Environmental Management 206(15): 863-871.

Yao, G., Gao, J., Zhang, C., Jiang, W., Wang, P., Liu, X., Liu, D., \& Zhou, Z. 2019. Enantio-selective degradation of the chiral alpha-cypermethrin and detection of its metabolites in five plants. Environmental Science and Pollution Research 26(2): 1558-1564.

Yekeen, T. A. \& Adeboye, M. K. 2013. Cytogenotoxic effects of cypermethrin, deltamethrin, lambdacyhalothrin and endosulfan pesticides on Allium cepa root cells. African Journal of Biotechnology 12(41): 6000-6006. 